\title{
MODEL PEMBELAJARAN BLENDED LEARNING PASCA NEW NORMAL COVID-19
}

\author{
Sy. Rohana ${ }^{1}$, Andi Syahputra ${ }^{2}$ \\ ${ }^{1,2}$ Sekolah Tinggi Agama Islam Negeri Teungku Dirundeng Meulaboh \\ Email kontributor: sy.rohana6@gmail.com
}

\begin{abstract}
Abstrak
Perubahan keadaan pembelajaran pada kondisi pasca new normal saat ini, pengajar dituntut dapat menyesuaikan dan mengembangkan model-model pembelajaran yang dapat memudahkan peserta didik memahami materi yang diajarkan. Selain itu, pengajar juga harus mampu menerapkan model yang berbasis tatap muka (tradisional) dan non-tatap muka (online). Oleh karena itu, model blended learning hadir menjadi salah satu model yang dapat menangani masalah tersebut. Model blended learning adalah proses pembelajaran yang memanfaatkan berbagai macam pendekatan, yaitu dengan memanfaatkan berbagai macam media dan teknologi secara offline maupun online. Model ini dapat meningkatkan akses, kemudahan siswa dalam mengakses materi pembelajaran, meningkatkan pengalaman baru mereka, meningkatkan kualitas pembelajaran, dan mengurangi biaya pembelajaran. Hasil kajian artikel ini menunjukkan bahwa model pembelajaran ini secara teori cocok diterapkan di sekolah maupun di perguruan tinggi pasca new normal, namun masih dibutuhkan penelitian lanjutan di lapangan untuk menguji keefektifannya.
\end{abstract}

Kata kunci: New Normal, Blended Learning

\begin{abstract}
The teachers are required to be able to adapt and develop their learning model in post-new normal condition at this time, the model should make the students to understand the material being taught easier. In addition, teachers must also be able to apply face-to-face (traditional) and non-face-to-face (online) model. Therefore, to solve the problem, there is an appropriate learning model, namely blended learning. Indeed, the blended learning model is a learning process that utilizes various approaches (i.e., media and technology) both offline and online. moreover, it can improve students' access in accessing learning materials, enhance their new experiences, improve the quality of learning, and reduce learning costs. As result, this article indicate that theoretically blended learning model can be a learning model in post-new normal at the school and university, but further research is still needed to examine the effectiveness of blended learning implementation.
\end{abstract}

Keywords: New Normal, Blended Learning 


\section{A. PENDAHULUAN}

New Normal adalah sebuah masa kebiasaan baru dimana kebiasaan melakukan dan menjalankan aktivitas seperti biasa namun selalu menerapkan Protokal Kesehatan (ProKes) di tengah Pandemi Covid-19. Pemerintah menghimbau kepada seluruh satuan pendidikan pada Zona Hijau untuk melakukan pembelajaran secara tatap muka dengan selalu mematuhi protokol kesehatan dan menjaga jarak (physical distancing) (Keputusan Bersama Menteri Pendidikan dan Kebudayaan No. 01/KB/2020, Menteri Agama No. 516 Tahun 2020, Menteri Kesehatan No. HK.03.01/Menkes/363/2020, 2020). Bramasta di dalam tulisannya mengutip pendapat Wiku Adisasmita, menurutnya New Normal adalah perubahan perilaku untuk tetap menjalankan aktivitas secara normal namun dengan ditambah menerapkan protokol Kesehatan guna mencegah terjadinya penularan COVID-19 (Bramasta, 2020)

Kenyataannya, kejadian ini menghambat segala aktifitas kehidupan manusia dari berbagai sektor, salah satunya adalah sektor pendidikan terutama pada proses baik di sekolah maupun di perguruan tinggi. Sebagai contoh, implementasi proses pembelajaran dimulai dari tahun 2020 sampai dengan tahun 2021 ini terjadi perbedaan yang signifikan dari tahun-tahun sebelumnya, sehingga para guru atau dosen harus mampu beradaptasi melakukan perubahan strategi atau model pembelajaran pada masa new normal ini. Selain itu, mereka juga dituntut untuk dapat menguasai dan menggunakan beberapa aplikasi online untuk menunjang proses pembelajaran mereka, seperti Zoom, Google Meet, Google Classroom, WhatsApp, E-learning online, dan lain sebagainya (Siti F, 2020).

Berkaitan dengan hal di atas, ini berarti telah terjadi perubahan pada dunia pendidikan masa kini, dimulai dengan menerapkan pembelajaran berbasis tatap muka menjadi berbasis tatap maya dengan menggunakan beberapa atau salah satu dari aplikasi online di atas (Heri, 2020). Di samping itu, apabila kita berbicara tentang proses pembelajaran tentunya tidak dapat dipisahkan dengan 3 (tiga) komponen yang melekat dalam proses pembelajaran itu sendiri, yakni kurikulum, pendidik (guru atau dosen), peserta didik (siswa atau mahasiswa). Ketiga komponen tersebut saling terkait satu sama lainnya dalam membentuk sebuah proses pembelajaran. Oleh karena itu, perlu adanya sebuah pembaharuan ketepatan di dalam memilih atau menggunakan sebuah model pembelajaran. Sebuah model pembelajaran dapat dikatakan baik sangat tergantung pada tujuan pembelajaran, kesesuaian dengan materi, kemampuan pendidik, perkembangan peserta didik, dan kemampuan mereka mengelola dan memberdayakan semua sumber belajar.

Secara teori, terdapat banyak model-model pembelajaran yang disesuaikan dengan zaman, tapi pada pasca new normal Covid-19 para pendidik cermat dalam memilih model-model pembelajaran yang efektif dan efisien untuk mencapai tujuan pembelajaran. Terutama pada era revolusi industri 4.0, mereka setidaknya dapat merubah tradisi pembelajaran, baik dalam memperoleh informasi, mengsinkronkan informasi, maupun meng-update informasi melalui pendidikan berbasis teknologi informasi sehingga mencapai tujuan dari sebuah pembelajaran (Syamsuar, S., \& Reflianto, 2019). Demikian pula bagi peserta didik diharapkan mereka mampu dengan mudah dapat menyerap informasi dengan cepat dan baik, karena segala sumber informasi saat ini tidak lagi terfokus pada teks - teks dari buku semata, akan tetapi lebih luas dari itu.

Dalam menentukan model pembelajaran, seorang guru atau dosen harus tahu bahwa model secara umum itu berfungsi sebagai kerangka konseptual yang dapat dijadikan sebagai pedoman atau sebagai acuan menerapkan sesuatu (Rusman, 2014). Jadi model pembelajaran 
adalah bentuk pembelajaran yang tergambar dari awal sampai akhir yang dilaksanakan oleh seorang guru dan dosen dengan baik. Selain itu, proses pembelajaran harus sistematis, dan direncanakan dengan baik. Setiap model pembelajaran membutuhkan sistem pengelolaan dan lingkungan belajar yang sedikit berbeda, artinya beda model pembelajran beda pula sistem pengelolaan dan lingkungan belajar.

Pasca new normal Covid-19 proses pembelajaran tidak cukup hanya berfokus pada pembelajaran online (e-learning), karena pembelajaran berbasis e-learning tidak dapat memenuhi tujuan pembelajaran sepenuhnya, akan tetapi ia dapat hanya dapat dijadikan pelengkap pembelajaran berbasis tatap muka (face-to-face) di kelas (Lewis, 2002). Handoko dan Waskito (2018) menambahkan bahwa pembelajaran e-learning hanya bergantung pada pembelajaran online, dan dapat berdampak positif dalam peningkatan kualitas. Namun, masih terdapat kekurangan bila diterapkan pada sekolah-sekolah formal, seperti di perguruan tinggi dan sekolah (Handoko \& Waskito, 2018). Oleh karena itu, Stein dan Graham (2014) menyatakan bahwa model blended learning adalah solusi yang tepat bagi pendidik dan peserta didik dalam kondisi di atas. Di samping penerapannya dapat menggabungkan model tatap muka (tradisional) dengan model online (e-learning), model ini dapat meningkatkan akses, kemudahan siswa dalam mengakses materi pembelajaran, meningkatkan pengalaman baru mereka, meningkatkan kualitas pembelajaran, dan mengurangi biaya pembelajaran (Stein \& Graham, 2014).

Handoko dan Waskito (2018) menyimpulkan bahwa implementasi model blended learning dapat berdampak efektif terhadap pembelajaran (Handoko \& Waskito, 2018). Model Blended learning dapat memenuhi tantangan 4 (empat) pembelajaran abad 21 yakni teknologi, strategi pembelajaran, cara baru berkomunikasi, dan penilaian (assessment) (Husamah, 2014). Bielawski dan Metcalf (2013) juga menyatakan bahwa model ini disampaikan melalui perpaduan harmonis antara pembelajaran virtual/maya dan tradisional dipimpin oleh instruktur atau pengajar (Bielawski, L \& Metcalf, 2003). Oleh karena itu, perpaduan kedua model tersebut dapat menjadikan Blended learning sebagai model pembelajaran pasca new normal COVID-19 dan bahkan akan menjadi trend di masa depan.

\section{B. METODE PENELITIAN}

Penulisan jurnal ini menggunakan metode kajian pustaka. Penelitian Pustaka adalah untuk membantu penulis dalam menentukan apakah judul akan dibahas layak atau tidak untuk dibahas . penelitian Pustaka juga akan memberikan pengetahuan yang luas bagi penulis dalam membatasi ruang lingkup pembahasannya (Adhi Kusumastuti dan Ahmad Mustamil Khoiron mengutip dari Creswell, 2010).

Ada beberapa macam bentuk kajian Pustaka, seperti ensiklopedia, kamus-kamus, bukubuku teks, direktori atau buku pegangan, biografi, indek, abstrak, laporan penelitian, majalah dan jurnal, skripsi, thesis dan desertasi. Selanjutnya disamping bentuk-bentuk kajian Pustaka ada beberapa tujuan kajian Pustaka, bahwa peneliti/ penulis dalam melakukan kajian Pustaka dilakukan sebelum menulis kajian atu penelitian, dengan tujuan; mencari informasi yang relevan dengan masalah yang akan dikaji atau diteliti, memperdalam pengetahuan penulis atau peneliti terkai dengan masalah dan bidang yang hendak dikaji dan diteliti, mengkaji teori-teori yang relevan sebagai landasan untuk menentukan teori yang tepat dan sesuai dengan kajian atau penelitian, mengkaji hasil penelitian terdahulu yang ada kaitannya dengan kajian sehinmgga 
tidak sama dengan penelitian orang, mendapatkan informasi tentang aspek mana judul kajian yang sudah pernah dibahas agar terhindar dari duplikasi. (Adhi Kusumastuti dan Ahmad Mustamil Khoiron mengutip dari Menurut Mukadis, Ibnu, Dasna 2003). Penelitian dan kajian Pustaka adalah penelitian dan kajian dengan cara menelaah buku-buku, jurnal, kamus, majalah biografi dan lainya yang relevan sebagai sumber dalam menulis atau pernelitian

\section{HASIL DAN PEMBAHASAN}

Pandemi covid 19 sangat berdampak terhadap kehidupan, virus ini sangat cepat tertular kepada orang lain hampir di semua negara termasuklah Indonesia di dalamnya. Karena penularannya sangat cepat maka pemerintah mengambil kebijakan dengan menerapkan PSBB (Pembatasan Sosial Berskala Besar). Kebijakan ini tentunya akan membawa dampak yang sanbgat besar dalam berbagai bidang, salah satunya bidanhg pendidikan. Atas dasar itu Kementerian Pendidikan dan Kebudayaan Republik Indonesia mengambil langkah diantaranya setiap sekolah melaksanakan pembelajaran di rumah. Kemudian pada masa New Normal Blended Learning memberi solusi sebagai model dari sebuah pembelajaran di masa New Normal.

Blended Learning mampu beradaptasi dengan kondisi new normal untuk meningkatkan proses pembelajaran dalam lingkungan pendidikan. sistem pembelajaran blended learning merupakan gabungan antara proses tatap muka (ofline) dengan mengajar secara online. (Suswarno. Dkk JAIM UNIK /Vol.4.No. 1. November 2020). Kombinasi pembelajaran masa new normal merupakan model pembelajaran yang sangat efektif karena pembelajaran blended learning sebuah bentuk pembelajaran daring dan luring.(Medina Nur Asyifah Purnama, SCAFFOLDING: Jurnal Pendidikan Islam Dan Multikulturalisme, Vol. 2, No. 2. September 2020). Ada lima unsur dapam pelaksanaan Blended Learning di masa New Normal, tatap muka, belajar mandiri, aplikasi kelas online, kerjasama,dan evaluasi (Jarwati, Dewi Priskawati Jurnal Pendidikan).

Berdasarkan dari beberapa penjelasan diatas maka, blended learning adalah sebuah model pembelajaran dengan memadukan dua pembelajran yaitu of line dan online, dengan tujuan utamanya adalah untuk menghasilkan efektivitas pembelajaran di masa new normal, sehingga proses pembelajaran menjadi lebih optimal.

\section{Dasar Pertimbangan Pembelajaran Pasca New Normal COVID-19.}

Berikut beberapa dasar pertimbangan diberlakukannya pembelajaran pasca New Normal COVID-19:

a. Surat Edaran Direktur Jenderal Pendidikan Islam Nomor: B-3095/DJ.I/12/2020 tentang Penyelenggaraan Pembelajaran Semester Genap Tahun Akademik 2020/2021 di Perguruan Tinggi Keagamaan Islam (PTKI).

Pada Surat Edaran di atas disampaikan bahwa pelaksanaan proses perkulihan dapat dilaksanakan secara tatap muka apabila mendapat rekomendasi dari Satuan Tugas (Satgas) Penangan COVID-19 di Kabupaten/Kota setempat. Selanjutnya, apabila tidak memungkinkan, PTKI wajib mengakomodasi kebutuhan perkuliahan melalui daring atau blended learning.

b. Keputusan Bersama Menteri Pendidikan dan Kebudayaan, Menteri Agama, Menteri Kesehatan, dan Menteri Dalam Negeri Republik Indonesian Nomor 04/KB/2020, 
Nomor 737 Tahun 2020, Nomor HK.01.08/Menkes/7093/2020 Nomor 420-3987

Tahun 2020 Tentang Panduan Penyelenggaraan Pembelajaran pada Tahun Ajaran 2020/2021 dan Tahun Akademik 2020/2021 di Masa Pandemi Corona Virus Disease 2019 (COVID-19).

Pada point VIII SKB 4 Menteri di atas disebutkan bahwa Pembelajaran tatap muka di satuan pendidikan dilaksanakan melalui dua fase sebagai berikut:

a. Masa Transisi

1) Berlangsung selama 2 (dua) bulan sejak dimulainya pembelajaran tatap muka di satuan pendidikan.

2) Jadwal pembelajaran mengenai jumlah hari dalam seminggu dan jumlah jam belajar setiap hari dilakukan dengan pembagian rombongan belajar (shift) yang ditentukan oleh satuan pendidikan dengan tetap memperhatikan kondisi kesehatan dan keselamatan warga satuan pendidikan.

b. Masa Kebiasaan Baru

Setelah masa transisi selesai, apabila kepala daerah atau kantor wilayah Kementerian Agama provinsi atau kantor Kementerian Agama kabupaten/kota tidak mencabut pemberian izin pembelajaran tatap muka, maka satuan pendidikan masuk dalam masa kebiasaan baru.

Sejak berlakunya SE Dirjend Pendidikan Islam di atas, proses perkuliahan pada beberapa Perguruan Tinggi Keagamaan Islam (PTKI) dilaksanakan ada secara tatap muka dan ada secara daring atau blend learning. Hal ini terjadi, karena ada beberapa Kabupaten/Kota setempat masih berstatus Zona Hijau, Kuning, dan Merah. Selain itu, SKB 4 Menteri tersebut menyebutkan bahwa proses pembelajaran di sekolah-sekolah dan madrasah-madrasah dirubah dan dilaksanakan secara sistem shift, yaitu dalam satu rombongan belajar (rombel) dibagi menjadi dua rombel dengan jadwal sekolah rombel satu sekolahnya Senin, Rabu, dan Jumat. Sedangkan rombel kedua sekolahnya Selasa, Kamis, dan Sabtu.

Oleh sebab itu, untuk kondisi pasca New Normal COVID-19, penulis sependapat bila pelaksanaan proses pembelajaran atau perkuliahan di sekolah, madrasah-madrasah, dan di perguruan-perguran tinggi diselenggarakan melalui model pembelajaran Blended learning (proses pembelajaran $50 \%$ daring dan $50 \%$ tatap muka). Karena proses pembelajaran model ini ]berbasis teknologi menggunakan internet dan lebih fleksibel dapat dilaksanakan dimana saja (online learning). Begitupun, proses pembelajaran melalui tatap muka dapat dijadikan pelengkap atau penguatan pendalaman materi selanjutnya.

\section{Proses Pembelajaran New Normal COVID-19.}

Setelah menghadapi masa pandemi COVID-19, sekarang sekolah-sekolah dan perguruan tinggi bersiap-siap memasuki masa new normal baru. Dengan memasuki era new normal berarti kita sudah boleh kembali melaksanakan proses pembelajaran tatap muka di sekolah-sekolah dan di perguruan tinggi. Para anak didik dan mahasiswa berharap agar guru dan dosennya merevolusi model pembelajran konvensional ke model pembelajran modern. Model dan konsep 
pembelajaran moderen yang sangat relevan pasca new normal diantaranya adalah blended learning

Dalam konteks pendidikan, disadari atau tidak, "new normal" telah mulai terjadi secara global sejak pandemi COVID-19. Kegiatan belajar mengajar yang bisanya dilaksanakan secara tatap muka secara langsung, guru dan dosen, anak didik dan mahasiswa hadir secara fisik di ruang-ruang kelas dan tempat-tempat belajar, kini digantikan dengan kegiatan pembelajaran melalui daring atau media elektronik (e-learning).

Untuk bisa terlaksananya proses pembelajaran secara maksimal perlu dikombinasikan antara proses pembelajaran tatap muka (offline) dengan online learning yaitu blended learning. Dengan demikian guru dan dosen bisa melihat bagaimana potensi anak didik dan mahasiswanya secara langsung. Disamping itu idealnya sebuah pembelajaran bia seorang guru dan dosen mampu mendorong kreativitas anak didik dan mahasiswanya secara keseluruhan sehingga membuat anak didika dan mahasiswanya aktif, dan mencapai tujuan dari sebuah pembelajaran. Di era new normal pembelajaran ideal itu merupakan tantangan tersendiri bagi sekolah-sekolah dan perguruan tinggi, baik guru, dosen, anak didik, mahasiswa juga para orang tua.

Menurut opini Faizah (2020), untuk terealisasinya Proses Belajar Mengajar (PBM) tahun ajaran baru sepenuhnya pada era new normal, perlu adanya kerjasama dari semua stakeholder dunia Pendidikan, seperti: sosialisasi dan diskusi sekolah dengan guru, guru dengan orang tua yang akan memantau pembelajaran anak-anak mereka dirumah (Faizah, 2020). Oleh karena itu, Faizah menambahkan ada beberapa hal yang semestinya dilakukan oleh guru dan dosen untuk menciptakan pembelajaran yang ideal di era new normal, yakni:

a. Mengimplementasikan metode pembelajaran berbasis pembelajaran daring (dalam jaringan) yang tepat sesuai dengan kemampuan peserta didik baik di sekolah dan kampus. Selain itu, menerapkan juga pembelajaran berbasis pembelajaran luring (luar jaringan). Pembelajaran ini menuntut siswa atau mahasiswa mengunggah dan mencetak terlebih dahulu materi pembelajaran (seperti bahan bacaan, video pembelajaran, artikel ilmiah, dan lain sebagainya) dari internet maupun media lainnya yang disediakan guru dan dosen.

b. Menyediakan beberapa pertanyaan berupa tugas ataupun hasil evaluasi yang tidak memberatkan peserta didik sesuai dengan tujuan pembelajaran.

c. Rencana Pelaksanaan Pembelajaran (RPP) atau Rencana Pembelajaran Semester (RPS) yang telah disusun sebelumnya dikaji ulang kembali dan tidak perlu dirubah secara total, akan tetapi, cukup disesuaikan dengan capaian pembelajaran antara proses pembelajaran berbasis e-learning dan tatap muka.

d. Menentukan metode atau teknik penilaian (assessment) yang sesuai bagi setiap capaian pembelajaran.

e. Menyesuaikan waktu efektif pembelajaran daring sesuai dengan tingkat kemapuan afektif dan kemampuan metakognitif peserta didik. Begitupun dalam hal pemberian tugas. Beban tugas yang berlebihan dapat menyita waktu belajar mereka.

f. Memotivasi peserta didik untuk tetap semangat dalam belajar walaupun melalui pembelajaran berbasis e-learning, dan sesekali memberikan reward kepada mereka sebagai nilai tambahan. 
g. Menjalin komunikasi harmonis dengan para orang tua atau wali murid untuk mengetahui hambatan atau masalah yang dihadapi anak-anak mereka selama melakukan pembelajaran secara daring maupun luring dirumah.

h. Kreasikan tugas yang bersifat open minded, mengutamakan motivasi anak didik lebih banyak mengalami (berbuat atau mengamati), melakukan interaksi, komunikasi, dan melakukan feedback dalam mengkonstruksi pengetahuan sehingga mereka dapat belajar secara bermakna.

Berdasarkan pendapat di atas, maka yang harus di laksanakan ketika menerapkan pembelajaran daring adalah harus mempersiapkan seperti point tersebut sehingga dapat terlaksana pembelajaran dengan baik. Apalagi dengan adanya keputusan dan kebijakan pemerintah pada semester genap 2020-2021 proses pembelajran harus dengan tatap muka (offline), dengan tetap mematuhi atau menerapkan standar protokol kesehatan COVID-19. Selanjutnya bila proses pembelajaran online masih juga berlanjut, maka guru dan dosen juga harus mampu menggunakan literasi digital agar pembelajaran secara daring dapat dilaksanakan dengan baik. Salah satu model pembelajaran yang sesuai kondisi new normal COVID-19 adalah model Blended Learning dapat dilaksanakan.

\section{Model Pembelajaran Blended Learning}

Model adalah bentuk atau bisa juga contoh yang tersusun secara sistematis. Sedangkan pembelajaran adalah proses interaksi seorang anak didik dengan gurunya atau seorang mahasiswa dengan dosennya untuk membantu anak didik dan mahasiswa agar dapat belajar dengan baik dan terarah dalam sebuah lembaga Pendidikan.

Proses pembelajaran di kelas telah kehilangan daya tariknya apalagi di era pandemi covid 19. Selain itu, perkembangan teknologi yang semakin luas menyebabkan proses pembelajaran di era 21 dapat dilakukan secara online (e-learning). Blended learning adalah model pembelajaran yang mengkombinasi keunggulan yang dimiliki model pembelajaran tatap muka (face-to-face) dengan model pembelajaran e-learning. Dengan blended learning interaksi dan komunikasi antar siswa dan antara guru dan siswa dapat terus berlangsung dan hal tersebut merupakan daya tarik pembelajaran di era 21 (Wardani, (2018).

Blended Learning sebuah model pembelajaran dengan memadukan pembelajaran Offline dengan materi online secara baik, artinya perpaduan antar pembelajaran konvensioanal dimana guru, dosen dan anak didik, mahasiswa bertemu sercara langsung dengan proses pembelajaran secara online yang bisa dilaksanakan kapan saja dan dimana saja (Handoko \& Waskito, 2018). Bisa juga dalam bentuk lain dari model blended learning adalah secara virtual antara anak didik, mahasiswa dengan guru dan dosennya, dan bisa saja mereka tidak berada di tempat yang sama, tapi di masing-masing tempat meraka sendiri, walaupun demikian mereka bisa saling bertanya dan memberi jawaban (saling memberi feedback). Proses pembelajaran tersebut dilakukan secara real time.

Melaksanakan pembelajran dengan model Blended Learning memberi kesempatan yang baik untuk belajar dari kelas dan transisi ke e-learning. Model pembelajaran ini melibatkan kelas atau tatap muka (offline) dan belajara online. Model Blended Learning ini sangat efektif dilaksanakan pasca new normal COVID-19. 


\section{a. Pengertian Blended Learning}

Blended Learning merupakan istilah yang berasal dari bahasa Inggris yang terdiri dari dua kata yaitu blended dan learning. Blended berarti campuran dan learning berarti pembelajaran. Dengan demikian model pembelajaran blended learning adalah sebuah model pembelajran yang mengandung unsur campuran atau penggabungan antara pembelajaran ofline ( tatap muka) dengan pembelajran online. Hal ini untuk meningkatkan pembelajaran mandiri secara aktif oleh anak didik dan mahasiswa serta untuk mengurangi jumlah tatap muka di kelas pasca new normal COVID-19.

Blended learning adalah strategi pembelajaran yang memanfaatkan teknologi internet (ELearning) yang dikombinasikan dengan tatap muka di kelas. Tujuan Penelitian ini adalah untuk peningkatan hasil belajar siswa, kegiatan mengajar guru, kegiatan belajar siswa, dan respon siswa dalam penerapan strategi pembelajaran Blended Learning (Rizkiyah, 2015).

Menurut Yusuf sebagaimana dikutip oleh Husamah (2014) secara konseptual, blended learning masih diperdebatkan secara sinis menyebutnya sebagai useless concepts (konsep yang tidak berguna), karena meragukan dampak pendekatan itu secara faktual terhadap hasil belajar. Namun sebagai riset justru menunjukkan bahwa pendekatan blended learning cepat atau lambat akan menggantikan model pembelajaran tradisional karena terjadi percepatan ganda dalam cara anak didik dan mahasiswa memenuhi kebutuhannya. Tren semakin hari menunjukkan perkembangan ke arah dimana blended learning akan mendapatkan proporsi lebih besar dan akan menggantikan model pembelajaran tradisional dan e-learning. Blended learning membantu pengalaman kelas dengan mengembangkan inovasi teknologi informasi dan komunikasi (Husamah, 2014)

Selanjutnya, Semler (2005) menambahkan bahwa Blended learning adalah mengkombinasikan aspek terbaik dari pembelajaran online, aktivitas tatap muka terstruktur, dan praktik dunia nyata. Sistem pembelajaran online, latihan kelas, dan pengalaman on-the-job akan memberikan pengalaman berharga bagi diri mereka. Blended learning menggunakan pendekatan yang memberdayakan berbagai sumber informasi yang lain (Semler, 2005)

Di samping itu, Purtadi juga menjelaskan di dalam buku Husaman (2014) bahwa blended learning adalah kombinasi berbagai media pembelajaran yang berbeda (teknologi, aktivitas, dan berbagai jenis peristiwa) untuk menciptakan program pembelajaran yang optimal untuk audiens (anak didik dan mahasiswa ) yang spesifik. Istilah blended sendiri berarti bahwa pembelajaran tradisional di dukung dengan format elektronik yang lain. Program blended learning menggunakan berbagai e-learning, mungkin digabungkan dengan pelatihan yang terpusat pada instruktur dan format langsung lainnya. efektif, diterapkan dalam cara yang terkoordinasi untuk mencapai tujuan pembelajaran yang diinginkan." (Husamah, 2014)

\section{b. Tahapan Model Pembelajaran Blended Learning}

Dalam model pembelajaran apapun seorang guru dan dosen harus mengembangkan model pembelajaran dengan baik. Baik secara konvensional maupun modern salah satunya model pembelajaran blended learning. Seorang guru dan dosen harus mengembangkan langkahlangkah pembelajaran secara tepat dalam suatu rencana pelaksanaan pembelajaran (RPP) berdasarkan kompetensi dasar yang hendak dicapai dalam sebuah pembelajaran.

Menerapkan model Blended learning perlu mengembangkan langkah-langkah pembelajaran dengan baik, dengan demikian dalam pelaksanaan pembelajaran anak didik dan 
mahasiswa tidak merasa kesulitan secara teknis. Maka guru dan dosen perlu mempersiapkan segala kebutuhan untuk proses pembelajaran seperti materi yang hendak diberikan, platform yang akan digunakan dalam proses pembelajaran blended learning dan platform teknologi yang akan digunakan dalam pembelajaran dengan tidak menggunakan tatap muka. Ada beberapa platform yang dapat digunakan WhatsApp, Google Classroom, Google Meet, Zoom Meeting, Edmodo dan lain-lain.

Semler (2005) menyarankan enam tahapan dalam merancang penyelenggaraan pembelajaran dengan menggunakan model blended learning supaya hasilnya baik (Semler, 2005), diantaranya adalah :

1. Tetapkan macam dan materi bahan ajar, ada tiga macam materi ajar diantaranya;

2. Tetapkan rancangan blended learning yang digunakan

3. Tetapkan format online learning

4. Lakukan uji terhadap rancangan yang dibuat

5. Selenggarakan blended learning dengan baik

6. Siapkan kriteria evaluasi pelaksanaan blended learning.

Tahapan tersebut harus dipahami oleh seorang guru dan dosen, artinya ia harus paham bahan ajar seperti apa yang relevan bila diterapkan pembelajaran jarak jauh. Kemudian rancangan pembelajaran harus nenar-benar dirancang dengan baik dan melibatkan ahlinya untuk membantu agar anak didik dan mahasiswa mudah dalam mengaksesnya. Ada hal yang perlu diperhatikan dalam membuat rancangan pembelajaran blended learning diantaranya; bagaimana bentuk materi akan disajikan, memilih materi apa yang wajib dipelajari dan materi sebagai anjuran, bagaimana anak didik dan mahasiswa bisa mengakses materi pembelajaran, dan faktor pendukung lainnya untuk terselenggaranya sebuah pembelajaran dengan baik.

Dalam proses pembelajaran blended learning seorang guru dan dosen juga harus menetapkan kriteria dalam melakukan evaluasi dalam sebuah pembelajaran. Berikut 6 (enam) kriteria evaluasi yang dapat dilakukan (Sjukur, 2012), yakni:

1. Ease to navigate, artinya seberapa mudahnya anak didik dan mahasiswa bisa mengakses informasi yang disediakan di paket pembelajaran, dengan kriteria makin mudah diakses makin baik.

2. Content, artinya bagaimana kualitas isi yang dipakai, contohnya bagaimana petunjuk mempelajarai materi ajar itu disiapkan, apa sudah sesuai dengan tujuan pembelajaran, dengan kriteria semakin medekati isi materi ajar dengan tujuan pembelajaran makla semakin baik.

3. Layout/ format/appearance, artinya paket pembelajaran disajikan secara professional, dengan kriteria makin baik penyajian materi ajar semakin baik.

4. Interest, artinya seberapa besar paket pembelajaran yang disajiokan mampu menimbulkan daya tarik anak didik dan mahasiswa untuk belajar, dengan kriteria semakin tertariknya anak didi dan mahasiswa untuk belajar semakin baik.

5. Applicability, arinya seberapa jauh paket pembelajaran yang bisa dipraktikkan secara mudah, dengan kriteria semakin mudah dipraktikkan semakin baik.

6. Cost-effectiviness/value, artinya seberapa murah biaya yang dikeluarkan untuk mengikuti paket pembelajaran, dengan kriteria semakain murah biaya paket pembelajran semakin baik. 
Dalam pembelajaran blended learning kegiatan evaluasi, kendala yang menonjol adalah tidak-mudahnya menjaga keabsahan mahasiswa dalam menunjukkan kemampuannya karena sulitnya mengecek apakah ada bantuan orang lain pada saat evaluasi itu dilakukan. Di sini faktor kejujuran dan otentisitas menjadi taruhan. Sedang keunggulan yang dirasakan menyangkut fleksibilitas waktu, dan evaluasi kapan saja dapatg dilakukan.

\section{Kelebihan dan Kekurangan Model Pembelajaran Blended Learning}

Ada beberapa pendapat tentang kelebihan dan kekurangan model blended learning, yaitu:

a. Husamah (2014) di dalam bukunya mengutip pendapat Kusairi dan Noer, kelebihan Blended Learning sebagai berikut:

1) Peserta didik akan bebas mempelajari materi pelajaran secara mandiri, materi yang tersedia secara online;

2) Guru atau dosen dan peserta didik dapat berdiskusi di luar jam tatap muka;

3) Kegiatan di luar jam tatap muka dapat dikelola dan dikontrol dengan baik oleh pengajar;

4) Pembelajaran lebih efektif dan efisien. Terutama di dalam pemberian tugas, feedback dan hasil evaluasinya melalui media internet;

5) Siswa ataupun mahasiswa dapat saling berbagi file dengan yang lainnya;

6) Pengajar dapat menambah materi pengayaan.

Adapun kekurangannya:

1) Media yang dibutuhkan sangat beragam, sehingga sulit diterapkan apabila sarana dan prasarana tidak mendukung.

2) Tidak meratanya fasilitas yang dimiliki anak didik dan mahasiswa, seperti komputer dan akses internet. Padahal dalam blended learning diperlukan akses internet yang memadai, apabila jaringan kurang memadai akan menyulitkannya dalam mengikuti pembelajaran mandiri via online.

3) Kurangnya pengetahuan masyarakat terhadap penggunaan teknologi.

4) Guru dan dosen perlu memiliki keterampilan dalam menyelenggarakan elearning

5) Guru dan dosen perlu menyiapkan waktu untuk mengembangkan dan mengelola pembelajaran sistem e-learning, seperti mengembangkan materi, menyiapkan assesment, melakukan penilaian, serta menjawab atau memberikan pernyataan pada forum yang disampaikan oleh anak didik dan mahasiswa.

6) Guru dan dosen perlu menyiapkan referensi digital sebagai acuan anak didik dan mahasiswa juga referensi digital yang terintegrasi dengan pembelajaran tatap muka

7) Diperlukan strategi pembelajaran oleh guru dan dosen untuk memaksimalkan potensi blended learning.

b. Fathurrahman dan Nurthpaturahman (2015) menambahkan ada beberapa kelebihan dan kekurangan yang kita dapati setelah kita melaksanakan proses pembelajaran dengan model blended learning (Fathurrahman \& Nuthpaturahman, 2015), kelebihan dan kekurangan tersebut diantaranya:

Kelebihan: 
1) Biaya dan waktu lebih hemat.

2) Proses pembelajaran lebih efektif dan efisien.

3) Peserta didik mudah dalam mengakses materi pembelajaran.

4) Peserta didik dengan bebas dan leluasa dalam mempelajari materi pembelajaran secara online.

5) Peserta didik mendapatkan diskusi lebih di luar jam tatap muka.

6) Guru dan dosen dapat memperoleh hasil belajar dengan baik.

7) Dengan proses pembelajaran blended learning ini dapat meningkatkan daya tarik pembelajaran peserta didik.

Kekurangan:

1) Prasarana dan sarana pendukung yang tidak memadai.

2) Tidak semua anak didik dan mahasiswa memiliki fasilitas HP.

3) Banyaknya yang melaksanakan proses pembelajaran daring pasca COVID-19 dan pasca new normal, maka dengan sendirinya akses internet tidak lancar.

4) Guru dan dosen harus mendesain proses pembelajaran dengan baik untuk anak didik dan mahasiswanya secara online.

Dalam proses penilaian dan evaluasi hasil dari pembelajaran tidak otentik, karena guru dan dosen tidak tatap muka langsung.

\section{KESIMPULAN}

Proses pembelajaran maupun perkuliahan di masa pasca New Normal COVID-19 dituntut untuk dapat diselenggarakan baik secara virtual (online) maupun secara tatap muka sesuai dengan peraturan yang telah diterbitkan oleh pemerintah. Namun, masih terdapat beberapa sekolah di sebagian daerah belum mampu menerapkan keduanya sekaligus. Oleh karena itu, pemerintah menawarkan salah satu model yang efektif untuk menangani masalah tersebut, yakni model Blended Learning.

Model Blended Learning memberikan kemudahan bagi siswa/mahasiswa di kelas mereka, karena model ini dapat menggabungkan sistem pembelajaran sebelumnya (tatap muka) dengan system pembelajaran saat ini (non-tatap muka/e-learning). Adapun, penggabungan kedua sistem tersebut bertujuan untuk meningkatkan pemahaman mereka dan mengembangkan keterampilan komputerisasi mereka.

Artikel ini ini merupakan hasil pengembangan konsep mendalam tentang model Blended Learning di masa pasca New Normal COVID-19. Artikel ini juga merekomendasikan kepada peneliti selanjutnya agar dapat melakukan penelitian lapangan lanjutan untuk mengukur keefektifan implementasi dan hambatannya.

\section{DAFTAR PUSTAKA}

Adi Kumastuti dan Ahmad Mustamil Khoiron (2019), Metode Penelitian Kualitatif, Lembaga Pendidikan Sukarno Pressindo.

Bielawski, L \& Metcalf, D. (2003). Blended eLearning: Integrating Knowledge, Performance Support, and Online Learning. Amherst, MA: HRD Press.

Bramasta, D. B. (2020). Mengenal Apa itu New Normal di Tengah Pandemi Corona ... Retrieved February 22, 2021, from https://www.kompas.com/tren/read/2020/05/20/063100865/ mengenal-apa-itu-new-normal-di-tengah-pandemi-corona- 
Faizah, A. (2020). Pembelajaran yang Ideal di Era New Normal.

Fathurrahman \& Nuthpaturahman. (2015). Blended Learning. Banjarmasin.

Handoko \& Waskito. (2018). Blended Learning: Teori dan Penerapannya. Padang: Lembaga Pengembangan Teknologi Informasi dan Komunikasi (LPTIK) Universitas Andalas.

Hardani, dkk, (2020), Metode Penelitian Kualitatif dan Kuntitatif, Pustaka Ilmu.

Heri, D. (2020). Menyiapkan Pembelajaran dalam Memasuki "New Normal" dengan Blended Learning. Retrieved February 22, 2021, from http://pmplampung.kemdikbud.go.id/pocontent/uploads/New_Normal_Blended_Learning_artikel_sec.pdf

Husamah. (2014). Pembelajaran Bauran (Blended Learning). Prestasi Pustaka Publisher

Jarwati dkk, (2020). Blended Learning: Solusi Pembelajaran New Normal Untuk Pendidikan Agama Kristen Di Era Revolusi Industri 4.0, Jurnal Pendidikan DIDAXEI, 1(2)

Keputusan Bersama Menteri Pendidikan dan Kebudayaan No. 01/KB/2020, Menteri Agama No. 516 Tahun 2020, Menteri Kesehatan No. HK.03.01/Menkes/363/2020, dan M. D. N. N. 440-882 T. 2020. (2020). Panduan Penyelenggaraan Pembelajaran pada Tahun Ajaran 2020/2021 dan Tahun Akademik 2020/2021 di Masa Pandemi Corona Virus Disease 2019 (Covid-19). Retrieved February 19, 2021, from https://www.kemdikbud.go.id/main/blog/2020/11/pemerintah-daerah-diberikankewenangan-penuh-tentukan-izin-pembelajaran-tatap-muka

Lewis, D. . (2002). A Departure from Training by the Book, More Companies Seeing Benefits of E-learning. Boston: The Boston Globe.

Medina Nur Asyifah Purnama, (2020). Blended Learning Sebagai Sarana Optotimalisasi Pembelajaran Daring di Era New Normal, SCAFFOLDING: Jurnal Pendidikan Islam dan Multikulturalisme. 2 (2).

Rizkiyah, A. (2015). Penerapan blended learning untuk meningkatkan hasil belajar siswa pada mata pelajaran ilmu bangunan di kelas X TGB SMK Negeri 7 Surabaya. Jurnal Kajian Pendidikan Teknik Bangunan, 1(1/JKPTB/15).

Rusman. (2014). Seri Manajemen Sekolah Bermutu Model-Model Pembelajaran Mengembangkan Profesionalisme Guru (2nd ed.). Rajawali Pers.

Semler, S. (2005). Use Blended learning to Increase Learner Engagement and Reduce Training Cost. Retrieved February 20, 2020, from http://www.learningsim.com/content/lsnews/ blended_learning1.html

Siti F. (2020). Pembelajaran di Era New Normal. https://doi.org/10.31229/osf.io/vd6qc

Sjukur, S. (2012). Pengaruh Blended Learning terhadap Motivasi Belajar dan Hasil Belajar Siswa Tingkat SMK. Jurnal Pendidikan Vokasi, 2(3).

Stein, J., \& Graham, C. R. (2014). Essentials for Blended Learning. In Essentials for Blended Learning. https://doi.org/10.4324/9780203075258

Suwarno, dkk, (2020), Penerapan Blended Learning Dalam Rangka mempersiapkan Sekolah dan Masyarakat Untuk Tatanan kehidupan Baru, Jurnal JAIM UNIK 4(1)

Syamsuar, S., \& Reflianto, R. (2019). Pendidikan dan tantangan pembelajaran berbasis teknologi informasi di era revolusi industri 4.0. E-Tech: Jurnal Ilmiah Teknologi Pendidikan, 6(2). https://doi.org/https://doi.org/10.24036/et.v2i2.101343

Wardani, D. N., Toenlioe, A. J., \& Wedi, A. (2018). Daya tarik pembelajaran di era 21 dengan Blended Learning. Jurnal Kajian Teknologi Pendidikan, 1(1), 13-18. 